\title{
Placenta Percreta: A Rare Cause of Mid Trimester Cornual Uterine Rupture
}

\author{
Shikha Rani* and Mamta Rani \\ Department of Obstetrics \& Gynaecology, Government Medical College \& Hospital, India
}

Submission: January 22, 2018; Published: February 08, 2018

"Corresponding author: Shikha Rani, Antenatal Medical Officer cum Lecturer, Department of Obstetrics \& Gynaecology, Government Medical College \& Hospital, Chandigarh, India, Tel:+919646040559; Email: shikhataneja2000@yahoo.co.in

\begin{abstract}
Abnormal placentation and its complications had increased during the past few years. Ever increasing rates of cesarean section has been responsible for this. Placenta accreta is a life threatening condition. We are reporting a case of placenta percreta leading to cornual uterine rupture.
\end{abstract}

Keywords: Placenta Accrete; Uterine Rupture; Mid Trimester Collapse

\section{Introduction}

Various obstetrical causes of mid trimester collapse are known like incomplete abortion, ectopic pregnancy, uterine rupture, abruptio placenta, placenta previa and accreta and ovarian torsion. Spontaneous uterine rupture is an uncommon dreadful condition has been reported in 1 in 5000 deliveries [1]. Placenta percreta leading to uterine rupture is even rare. Placenta accreta is usually associated with some insult to uteruine endometrium, myometrium or vascular supply.

Various risk factors for placenta accreta are previous cesarean section, myomectomy, uterine curettage, advance maternal age, multiparity etc. [2]. Placenta accreta is mostly associated with some uterine insult and is mostly in lower segment [3]. However, we are reporting a case of fundal placenta percreta leading to cornual uterine rupture.

\section{Case Summary}

36 yrs pregnant women G3P1L1AI at 19+3 weeks with previous cesarean reported in our emergency department with complains of painless bleeding per vaginum. On admission her vitals were stable. Per abdomen examination revealed 18 weeks relaxed uterus. There was no bleeding on local examination. Ultrasonography revealed a single live breech fetus with placenta starting from fundus anteriorly and partially covering os. There were no signs of placenta accreta in the lower uterine segment. Her first baby was born 9yrs back by lower segment cesarean section in view of placenta previa. She had a spontaneous complete abortion of 10 weeks gestation and no instrumentation was done. After 48 hrs of conservative management patient was discharged.
She was readmitted at $22+5$ weeks with bleeding per vaginum associated with pain abdomen. On admission her vitals were stable. Per abdomen examination revealed 22 weeks relaxed uterus with soft abdomen. Per speculum examination showed closed so with minimal dark blood in vagina. On investigation her hemoglobin was $8.1 \mathrm{gm} \%$ and rest all investigations were normal. Ultrasonography confirmed the previous findings. On 4th day of readmission she complained persistent severe pain. Her pulse rate was $110 / \mathrm{min}$ low volume and blood pressure was $70 / 50 \mathrm{~mm}$ $\mathrm{Hg}$.Per abdomen guarding and rigidity, uterine height increased to 26 weeks and tenderness present all over. In suspicious of uterine rupture an urgent bed side ultrasonography was done. Ultrasound showed fundal uterine rupture with fetus lying in the peritoneal cavity. Immediate resuscitation was started and patient was shifted for laparotomy.

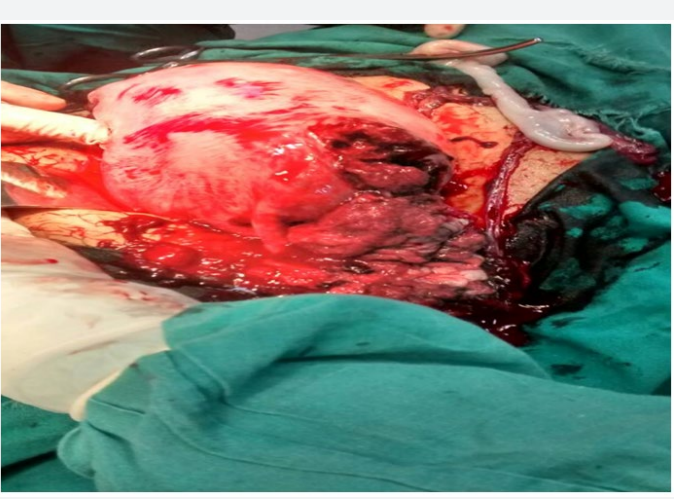

Figure 1: Left uterine cornual rupture.

Intra-operatively 1.7 liters of hemoperitoneum was present. Fetus was lying in the peritoneal cavity. Left uterine cornual 
rupture was present (Figure 1). Placenta was densely adherent to uterine muscle at left cornual end, same was removed in piece meal. A small piece of myometrial tissue from cornual end was sent for histo-pathological examination. Left sided cornual repair with left salpingectomy and right sided tubectomy was performed. Postoperative period remained uneventful and patient was discharged. Histopathology report confirmed placenta accreta (Figure 2).

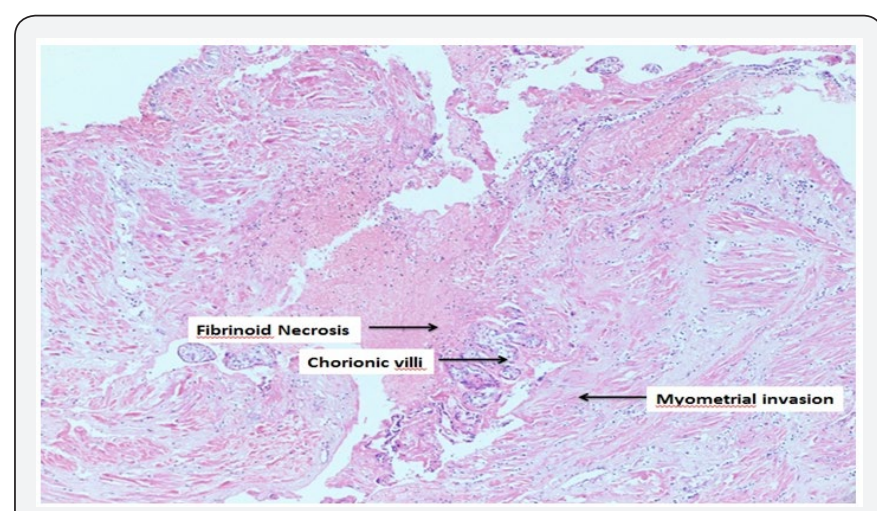

Figure 2: Chorionic villi invading the myometrial bundles with focal fibrinoid necrosis (H\&E; 100X).

\section{Discussion}

Placenta accreta is a nightmare for an obstetrician as it associated with lot of maternal morbidity and mortality. The exact etiology of placenta accrete is not clear. Multiple factors which can lead to abnormal placentation are loss of deciduas spongiosis, few decidual killer cells, relative hypoxia of cesarean scar tissue, increased trophoblastic inclusion $[4,5]$. This explains placenta accreta in sites other than lower uterine segment, patients without placenta previa, no history of uterine surgery or other high-risk situations. Like in our patient fundal placenta percreta leading to cornual rupture.

Ultrasonography is a very useful tool for screening of placenta accrete Ultrasound evidence of placenta accreta are placental lacunae, interruption or bulging in bladder wall, myometrial thickness $<1 \mathrm{~mm}$ at placental site, loss of clear space between myometrium and placenta, placenta invading the surrounding structures. On color Doppler turbulent blood flow extending from placenta into the surrounding tissues. Ultrasonography is the mainstay imaging for screening for placenta accreta. Magnetic resonance imaging is complementary to ultrasonography [3]. However, high index of suspicion is required o diagnosed upper segment placenta accreta.
Upper segment placenta accreta usually presents in early pregnancy as acute abdomen [6]. Similar has been reported by Jang et al. [7] a case of placenta percreta leading to fundal uterine rupture at 14 weeks of gestation [7]. It was incidentally diagnosed on laparscopy done for acute pain abdomen. Hornemann et al. [8] reported a case of placenta percreta induced uterine fundal rupture [8].

Except elderly women we couldn't find any other high risk factor for upper uterine segment placenta percreta in our patient. Also the patient denied any dilatation and curettage for the abortion. Due to which diagnosis is delayed in our patient. High index of suspicion can help in early diagnosis of this dreadful condition.

\section{Conclusion}

Recognition, readiness and swift response to this threatening condition can help to have good maternal outcome.

\section{Conflict of Interest}

There is no conflict of interest.

\section{References}

1. Turner MJ (2002) Uterine rupture. Best Pract Res Clin Obstet Gynaecol 16(1): 69-79.

2. Bowman ZS, Eller AG, Bardsley TR, Greene T, Varner MW, et al. (2014) Risk factors for placenta accreta: a large prospective cohort. Am J Perinatol 31(9): 799-804.

3. Riteau AS, Tassin M, Chambon G, Le Vaillant C, de Laveaucoupet J, et al. (2014) Accuracy of ultrasonography and magnetic resonance imaging in the diagnosis of placenta accreta. PLoS One 9(4): e94866.

4. Adler E, Madankumar R, Rosner M, Reznik SE (2014) Increased placental trophoblast inclusions in placenta accreta. Placenta. 35(12): 1075-1078.

5. Laban M, Ibrahim EA, Elsafty MS, Hassanin AS (2014) Placenta accreta is associated with decreased decidual natural killer (dNK) cells population: a comparative pilot study. Eur J Obstet Gynecol Reprod Biol 181: 284-288.

6. Comstock $\mathrm{CH}$ ( 2005 ) Antenatal diagnosis of placenta accreta: a review. Ultrasound Obstet Gynecol 26(1): 89-96.

7. Jang DG, Lee GS, Yoon JH, Lee SJ (2011) Placenta percreta-induced uterine rupture diagnosed by laparoscopy in the first trimester. Int J Med Sci 8(5): 424-427.

8. Hornemann A, Bohlmann MK, Diedrich K, Kavallaris A, Kehl S, et al. (2011) Spontaneous uterine rupture at the 21st week of gestation caused by placenta percreta. Arch Gynecol Obstet 284(4): 875-878. 
(C) This work is licensed under Creative BY
Your next submission with Juniper Publishers will reach you the below assets

- Quality Editorial service

- Swift Peer Review

- Reprints availability

- E-prints Service

- Manuscript Podcast for convenient understanding

- Global attainment for your research

- Manuscript accessibility in different formats

( Pdf, E-pub, Full Text, Audio)

- Unceasing customer service

Track the below URL for one-step submission https://juniperpublishers.com/online-submission.php 